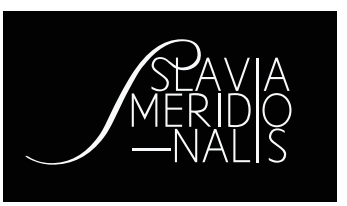

\title{
Anna Kozyra
}

Uniwersytet Mikołaja Kopernika w Toruniu

\section{Geminaty w językach słowiańskich ${ }^{1}$}

W ostatniej dekadzie Komisja Fonetyki i Fonologii przy Międzynarodowym Komitecie Slawistów pracuje intensywnie nad arealno-typologiczną charakterystyką fonetyki słowiańskiej. Efektem tych prac są, jak dotąd, dwie publikacje: Komparacja współczesnych języków słowiańskich 2, Fonetyka i Fonologia (Sawicka (red), 2007) oraz Sandhi w językach słowiańskich (2013). Na podstawie tych pozycji, jak również prac I. Sawickiej (Sawicka, 2001) i W. Pianki, E. Tokarza (Pianka \& Tokarz, 2000) można wskazać na szereg relewantnych dla problemu cech fonetycznych i fonologicznych oraz na dwa przeciwstawne bieguny arealno-typologiczne.

Do najważniejszych cech różnicujących języki słowiańskie należą: większy lub mniejszy udział palatalności w systemie fonologicznym, jak również obecność/brak palatalności asymilacyjnej, wokaliczność vs. konsonantyczność systemów fonologicznych, modele sylabiczne, grupy spółgłoskowe i grupy samogłoskowe, cechy prozodyczne, dotyczące tak akcentu wyrazowego,

1 Artykuł przedstawia wyniki większej niepublikowanej pracy (Kozyra, 2014).

This work was supported by the Polish Ministry of Science and Higher Education.

Competing interests: no competing interests have been declared.

Publisher: Institute of Slavic Studies PAS.

This is an Open Access article distributed under the terms of the Creative Commons Attribution 3.0 PL License (creativecommons.org/licenses/by/3.0/pl/), which permits redistribution, commercial and non-commercial, provided that the article is properly cited. (c) The Author(s) 2015. 
jak i intonacji frazowej, sandhi dźwięcznościowe i inne. Ustalenia zawarte w wymienionych pracach oparte są po części na badaniach szczegółowych poszczególnych problemów (najwięcej prac poświęcono strukturze sylaby i grupom spółgłoskowym, zob. Sawicka, 1974, 1986 i szereg artykułów szczegółowych, Лекомцева, 1968; Толстая, 1968a, 1968b, 1974, i in.), po części zaś na niezweryfikowanych informacjach pochodzących z opisów fonetyczno-fonologicznych poszczególnych języków.

Mając na uwadze fakt, że fonetyka słowiańska ulega szybkiej ewolucji, informacje te wymagają weryfikacji. Prace w tym kierunku podejmowane są przez członków Komisji (por. Cychnerska, 2012; Korytowska, 2001; Zinowiewa, $1998 \mathrm{i}$ in.).

Jednym z problemów, jakie wymagają sprawdzenia, jest zagadnienie geminacji spółgłoskowej.

Przeciwstawne bieguny słowiańskie, charakteryzujące się maksymalnym zróżnicowaniem w zakresie fonetyki, to biegun północno-wschodni (język rosyjski, a w odniesieniu do jednej cechy - struktury sylaby - polski), a z drugiej strony, biegun południowo-zachodni (obszar serbsko-chorwacki, a w odniesieniu do jednej cechy - frekwencji grup samogłoskowych - język macedoński). Między tymi krańcowymi typami fonetycznymi przejście jest stopniowe, języki klasyfikują się jako mniej lub bardziej należące do konkretnego typu, jednak zasadniczo możliwe jest wytyczenie między nimi granicy, która, według wymienionych prac, przebiega wzdłuż Karpat. W ten sposób granica ta rozbija języki zachodniosłowiańskie. Fonetyka czeska i fonetyka słowacka należą do typu południowego, zaś pozostałe języki zachodniosłowiańskie (wraz ze wschodniosłowiańskimi) - do typu północnego. Cezura ta, na podstawie najważniejszej cechy - palatalności, dzieli także obszar bułgarski na pół: dialekty wschodniobułgarskie zdecydowanie należą do typu północnego (północno-wschodniego), zaś zachodnie stanowią raczej obszar przejściowy do typu południowo-zachodniego (szczegóły zob. w wymienionej literaturze przedmiotu, zwłaszcza w: Komparacja współczesnych języków słowiańskich (Sawicka (red.), 2007)).

Na dwubiegunowy obraz fonetyki słowiańskiej nakłada się zróżnicowanie: fonetyka bałkańska vs. fonetyka niebałkańska. Ta pierwsza ma bardziej europejski charakter. Bałkańska Liga Językowa definiowana jest poprzez cechy morfoskładniowe. Zróżnicowania fonetyczne wyznaczają inne granice poszczególnych areałów typologicznych niż morfoskładnia. Mimo to postuluje się istnienie typu fonetycznego centralnobałkańskiego (por. Sawicka, 2001, Sawicka (red.) 2007). 
Fonetyka języków bałkańskich dzieli się na typ wschodni (bułgarsko-rumuński), nawiązujący do fonetyki północno-wschodnio-słowiańskiej (a w zasadzie do fonetyki euroazjatyckiej, zob. Jakobson, 1962), oraz na typ zachodni, europejski (pozostałe języki bałkańskie), który ma również pewne specyficzne cechy bałkańskie (areał centralnobałkański). Tak więc podział typologiczno-arealny słowiańszczyzny w znacznej części pokrywa się z podziałem areału bałkańskiego na typ wschodni (euroazjatycki) i zachodni (zachodnioeuropejski).

Problem geminacji spółgłoskowej jest relewantny dla obu tych podziałów. W literaturze przedmiotu ugruntowana jest opinia, że w językach południowosłowiańskich, a także w czeskim i słowackim geminaty spółgłoskowe nie występują. Brak geminacji ma też być cechą języków bałkańskich. Celem artykułu jest weryfikacja tego poglądu w odniesieniu do areału słowiańskiego.

W wyrazach rodzimych geminaty występują tylko na granicach morfologicznych, nie wszystkie z tych granic są odczuwane przez użytkowników języka jako cezury fonetyczne. Poza tym, geminaty przychodzą z zapożyczeniami z języków obcych, w zależności od języka i/lub wieku zapożyczenia - geminaty są upraszczane lub nie. Zdarzają się też spontaniczne geminacje na skutek fortycji. Ustalenie aktualnej sytuacji w zakresie występowania geminacji wydaje się sprawą prostą. Tak jednak nie jest, ponieważ znaczna część geminat spółgłoskowych w językach słowiańskich powstaje wskutek kombinatorycznych upodobnień, prowadzących do neutralizacji opozycji fonologicznych i większa część tych upodobnień ma charakter fakultatywny. Rzetelna ocena zjawiska wymaga szerszego zakresu badań, których nie sposób wykonać w ramach tego jednego przedsięwzięcia. Każdy język wymaga odrębnej rozbudowanej analizy na korpusie tekstów naturalnych. Podjęcie tematu w odniesieniu do całej słowiańszczyzny uzasadnia konieczność wstępnego rozeznania, badań o charakterze preliminarnym, sondażowym. I takie badanie stanowi przedmiot tego artykułu.

Podstawą oceny są segmenty, głoski. Ponieważ jednak w wyniku upodobnień kombinatorycznych, związanych $\mathrm{z}$ badanym kontekstem, najczęściej dochodzi do neutralizacji opozycji fonologicznej, geminaty są w większości reprezentowane przez podstawowe reprezentacje fonemów. Geminowane alofony należą do rzadkich wyjątków, jak np. w pol. melli, które może być wymówione bez geminaty [ll'], jak i z geminatą alofonu [l'l'] pod warunkiem, że palatalność włączy się od początku artykulacji zbitki.

Reguły asymilacji/neutralizacji, w wyniku których powstają geminaty, ustalono na podstawie fonetyczno-fonologicznych opisów poszczególnych 
języków słowiańskich. We wszystkich językach słowiańskich geminaty tego rodzaju powstają wskutek upodobnień spółgłosek właściwych pod względem dźwięczności, miejsca i sposobu artykulacji. Mając na uwadze liczne błędy występujące w słownikach ortoepicznych języka polskiego, a także zmienność w czasie fonetyki słowiańskiej, zrezygnowano z korzystania z poradników ortoepicznych. Zmiany lepiej śledzą opisy fonologiczne, które są formułowane częściej.

Inwentarz geminat nie jest specjalnie zróżnicowany, ale istotna różnica dotyczy frekwencji geminacji. Występowanie geminat w poszczególnych językach sprawdzono na podstawie pięćdziesięciostronicowych tekstów czytanych przez rodzimych użytkowników danego języka. Lektorów, w zależności od języka, było od dwóch do pięciu. W eksperymencie brali udział respondenci w wieku 20-40 lat, posługujący się kulturalną wymową. Jeżeli wyniki odczytów były rozbieżne, wybierano wariant wymowy, który powtórzony był więcej razy.

Badanie tekstów wykazuje istotne różnice we frekwencji geminat, jednak nie tak duże, jakby można oczekiwać na podstawie dotychczasowej wiedzy na ten temat.

Badaniu poddano 13 języków słowiańskich (polski, czeski, słowacki, rosyjski, białoruski, ukraiński, górnołużycki, dolnołużycki, słoweński, serbski, chorwacki, bułgarski i macedoński). Pominięto bośniacki, czarnogórski, kaszubski i rusiński.

Zasadniczym kontekstem występowania geminacji był wyraz prozodyczny, a więc jednostka charakteryzująca się określonymi sygnałami granicznymi, mająca jedną sylabę wyróżnioną. Tak zdefiniowany wyraz jest przeważnie podzielny morfologicznie. Niektóre z wewnątrzwyrazowych szwów morfologicznych są przez mówców uświadamiane i manifestowane, mniej lub bardziej regularnie, na płaszczyźnie fonetycznej. Są to jednostki nazywane w literaturze fonologicznej junkturami. Charakteryzują się one częściowo innym repertuarem zjawisk dystrybucyjnych niż pozycja wewnątrz morfemu. Część zjawisk fonetycznych występujących w kontekście junktur ma w językach słowiańskich charakter obligatoryjny (upodobnienia pod względem dźwięczności), część - fakultatywny (pozostałe rodzaje upodobnień), niektóre są bardziej regularne, inne mniej. Na podstawie mniej lub bardziej konfluentnej realizacji połączeń i różnic dystrybucyjnych, ujawniających się między tymi kontekstami a kontekstem wewnątrz morfemu/tematu, uważa się, że szwy morfologiczne mające wartość fonologicznej junktury to: szew między dwoma wyrazami prozodycznymi, szew po proklityce (przedrostku, przyimku, cząstce nie), szew 
przed enklityką i szew między członami wyrazów złożonych. Natomiast szew przed przyrostkiem czy końcówką fleksyjną nie różni się fonetycznie w żaden sposób od pozycji wewnątrz morfemu. Tak więc pozycja „wewnątrzmorfemowa” umownie obejmuje także szwy przed sufiksem i końcówką fleksyjną.

W szybkiej wymowie zdarza się, że dwa krótkie wyrazy akcentogenne, połączone ścisłym związkiem semantyczno-składniowym (głównie frazy nominalne), zlewają się w jeden wyraz prozodyczny. W takich wypadkach, w pozycji międzywyrazowej junktury zasadniczo zachowuje się fonetyka międzywyrazowa. Takie sytuacje w badanych tekstach nie wystąpiły, ponieważ tempo, w jakim respondenci czytali teksty, nie było szybkie - respondenci proszeni byli o staranne przeczytanie tekstu w tempie „normalnym”, przeciętnym dla tekstów czytanych.

Uzyskane wyniki potwierdziły, że występowanie geminat jest cechą różnicującą fonetykę języków słowiańskich. Nie potwierdziła się natomiast opinia, że w językach południowosłowiańskich, oraz czeskim i słowackim, geminaty nie występują. Różnica między językami słowiańskimi obecnie wiąże się z różną frekwencją geminacji w poszczególnych językach, a nie z brakiem/ obecnością geminacji.

Pogląd o braku geminacji na południu oparty jest na wcześniej istniejącej restrykcji. Świadectwa jej odnajdujemy w ortografii zwłaszcza tych języków, w których pisownia oparta jest na zasadzie fonetycznej, np. w serb. оделити, chorw. odijeliti (wobec pol. oddzielić), jak również formy wcześniej przyswojonych wyrazów obcych, por. np. serb. вила, либрето (wobec pol. willa, libretto) i in. W harmonii $\mathrm{z}$ wycofywaniem się restrykcji dotyczącej występowania geminat jest również zmiana sposobu realizacji geminat i powrót wymowy $\mathrm{z}$ geminatą $\mathrm{w}$ wyrazach, które wcześniej wymawiano z pojedynczą spółgłoską, jeśli na piśmie występuje zbitka takich samych liter. Najwyraźniej widać to w polszczyźnie, gdzie młodzież wymawia nagminnie miękki [m'jenk'k'i/m'jenkk'i], Westerplatte [vesterplatte], a starsi [m’jenk'i], [vesterplate] i in. Równocześnie wymowa wszelkich geminat przez młodzież staje się bardziej precyzyjna. W wymowie geminaty okluzywnej często wyraźnie realizowane są dwie plozje. Mniej płynne i dłuższe staje się połączenie dwóch szczelinowych. Z punktu widzenia wcześniejszej normy (por. opisy artykulacji takich kontekstów podawane w opisach fonologicznych - np. Bajerowa \& Wieczorkowa, 1989; Grzybowski, 1986, 2007; Serowik, 1998 - taka wymowa wydaje się sztuczna i nienaturalna, niemniej przez młodzież uważana jest za poprawną (lepiej odpowiadającą formie ortograficznej). Ortografia w ogóle odgrywa dużą rolę. Zachowanie geminat na piśmie w wypadku zapisu w języku 
źródłowym, umożliwia powrót do wymowy geminaty (tak jak w pol. pizza [p’icca], wcześniej [p'ica] i in.; por. wcześniej przytoczone przykłady). Zdarza się też, że świadomość budowy morfologicznej wyrazu pozwala na przywrócenie geminaty nawet mimo pisowni z pojedynczą spółgłoską. Zdarza się to na przykład w serbskim, gdzie na skutek występującej przez wieki restrykcji dotyczącej występowania geminat, większość leksyki rodzimej nie zawiera na piśmie geminat (por. np. бесмислен, одавно, бестидан, оделити). Obecnie jednak często zdarza się nawet realizacja np. [bezzakońe] безакоюе; oczywiście w wymowie często utrzymują się geminaty powstające na silnych szwach wewnątrzwyrazowych, np. најjачи [na:jjači], поддијалекат [poddijalekat], из собе [issobe], ноћас се [noćasse]. Rzadziej powracają geminaty w końcówkach, np. dativ/lokativ sg od бum-ka powinien brzmieć bitk-i > bitci, bicci. Zamiast tego używa się w serbskim [bitki] lub [bici]. Dziś z powrotem możliwe jest też [bicci].

Prócz geminat zapisanych w reprezentacji graficznej wyrazów, w wymowie występują też geminaty powstające na granicach morfologicznych $\mathrm{z}$ upodobnień. Regularne jest przejście /s/, /z/ w /š/, /ž/, por. np. serb. без шећера бе[šš]eћеpa, без шума бе[šš $] y \mathcal{M} a ; \mathrm{w}$ wolniejszym tempie wymowy na skutek afrykatyzacji mogą pojawić się geminaty [čč], [cc]: oтчепuтu o[čč] епити, отиепити о [cс]епити. Dotyczy to wszystkich języków słowiańskich. Wyjątki dotyczą jedynie ukraińskiego, w którym ubezdźwięcznienia są nieregularne (według oficjalnej normy w ogóle nie zachodzą), oraz słoweńskiego, w którym oprócz upodobnień regresywnych występują też progresywne, np. podse [potse]/[pocce]/[poce], pod šibo [potšibo]/[poččibo]/[počibo], pod žago [podžago]/[požžago]/[požago]. We wszystkich pozostałych językach słowiańskich wszelkie relewantne dla zjawiska geminacji asymilacje mają charakter regresywny ${ }^{2}$.

Zmiany w zakresie geminacji obserwujemy we wszystkich językach słowiańskich. Ponieważ jednak w każdym $\mathrm{z}$ nich inny jest punkt wyjścia, różnice typologiczne utrzymują się. Nie jest to już wprawdzie opozycja: obecność vs. brak geminat, ale większa vs. mniejsza frekwencja tekstowa geminat. Na podstawie pięćdziesięciostronicowych próbek możemy wyróżnić różne stopnie nasycenia tekstu geminatami.

Występowanie geminat, których wymowa jest konsekwencją zapisu ortograficznego i braku reguł redukujących geminaty, w poszczególnych językach wygląda następująco:

${ }^{2}$ Pomijam tu oczywiście procesy progresywne, jakie zaszły w ukraińskim i białoruskim po drugiej jotacji i doprowadziły do powstania dużej liczby geminat. Zjawiska te są już od dawna martwe. 
Tab. 1. Występowanie geminat „obligatoryjnych” w językach słowiańskich w badanych próbkach

\begin{tabular}{|c|c|c|c|}
\hline Język & $\begin{array}{c}\text { Liczba geminat } \\
\text { realizowanych obo- } \\
\text { wiązkowo }\end{array}$ & $\begin{array}{c}\text { Liczba geminat } \\
\text { w nagłosie }\end{array}$ & $\begin{array}{c}\text { Liczba geminat } \\
\text { wewnątrz morfemu/ } \\
\text { tematu }\end{array}$ \\
\hline \multicolumn{5}{|c|}{ JĘZYKI WSCHODNIOSŁOWIAŃsKIE } \\
\hline rosyjski & 1089 & 144 & 178 \\
\hline białoruski & 923 & 47 & 75 \\
\hline ukraiński & 959 & 31 & 63 \\
\hline \multicolumn{5}{|c|}{ JĘZYKI ZACHODNIOSŁOWIAŃsKIE } \\
\hline polski & 349 & 73 & 12 \\
\hline dolnołużycki & 5 & - & - \\
\hline górnołużycki & 6 & - & 3 \\
\hline słowacki & 81 & - & - \\
\hline czeski & 16 & 7 & - \\
\hline & JĘZYKI POŁUDNIOWOSŁOWIAŃSKIE & - \\
\hline bułgarski & 318 & 2 & - \\
\hline macedoński & 55 & - & - \\
\hline słoweński & 269 & - & - \\
\hline chorwacki & 52 & - & \\
\hline serbski & 78 & & \\
\hline
\end{tabular}

W tabeli specjalnie wyodrębniono pozycję nagłosu. W wygłosie geminaty nie występują w wymowie w żadnym języku słowiańskim. W większości języków słowiańskich geminaty nie występują również w nagłosie. Utrzymanie restrykcji zapewniają reguły morfonologiczne, np. w bułg. przyimek в przed nagłosowym $в$ - і $\oint$ - przybiera postać във (във влака, във виното, във фабриката, във фблотата), tak samo $c$ przed nagłosowym $c$ i $з$ brzmi сәс (сәс сила, сәс собствените, със суеверен, със земята, със замах, $c z c$ зависm, със завесu). Podobnie w serbskim $s$ ma również postać $c a$, a przyimek i przedrostek kontynuujący ps. ${ }^{\star} v \sigma$ ma postać $y$ (np. y води, улазити), со m.in. zapobiega powstaniu geminaty (np. yвозumu). Najbardziej sprzyjającą pozycją dla utrzymania geminaty jest pozycja interwokaliczna. Często zdarza się, że na szwach przedrostkowych geminata jest wymawiana w pozycji interwokalicznej, ale upraszcza się, jeśli wchodzi w skład grupy spółgłoskowej, np. w bułg. na granicach prefiksalnych иззвуча и[zv]уча, беззлобен бе[zł]обен, беззвучен бе[zv]учен. Podobnie na szwie rodzajnikowym np. mac. животта, пролетта, ale радоста, смрта.

W każdym języku ponadto występują $\mathrm{w}$ wymowie geminaty pochodzące $\mathrm{z}$ upodobnień, które wprawdzie są fakultatywne, lecz w normalnym tempie 
wymowy powszechne. Biorąc pod uwagę wszystkie zrealizowane w badanych tekstach geminaty sytuacja wygląda następująco:

Tab. 2. Geminaty wymówione w próbkach pięćdziesięciostronicowych tekstów słowiańskich

\begin{tabular}{|c|c|c|c|c|}
\hline Język & $\begin{array}{l}\text { Liczba geminat } \\
\text { zrealizowanych } \\
\text { w badanych } \\
\text { próbkach }\end{array}$ & $\begin{array}{c}\text { Z tego } \\
\text { wewnątrz mor- } \\
\text { femu/ tematu }\end{array}$ & $\begin{array}{c}\text { Na silnej } \\
\text { granicy morfo- } \\
\text { logicznej }\end{array}$ & $\begin{array}{c}\text { W nagłosie } \\
\text { wyrazu }\end{array}$ \\
\hline \multicolumn{5}{|c|}{ JĘZYKI WSCHODNIOSŁOWIAŃSKIE } \\
\hline rosyjski & 1158 & 178 & 980 & 144 \\
\hline białoruski & 926 & 75 & 851 & 47 \\
\hline ukraiński & 969 & 63 & 906 & 31 \\
\hline \multicolumn{5}{|c|}{ JĘZYKI ZACHODNIOSŁOWIAŃSKIE } \\
\hline polski & 510 & 12 & 498 & 73 \\
\hline dolnołużycki & 5 & - & 5 & - \\
\hline górnołużycki & 6 & - & 6 & - \\
\hline słowacki & 129 & 3 & 126 & - \\
\hline czeski & 53 & - & 53 & 7 \\
\hline \multicolumn{5}{|c|}{ JĘZYKI POŁUDNIOWOSŁOWIAŃSKIE } \\
\hline bułgarski & 357 & - & 357 & 2 \\
\hline macedoński & 56 & - & 56 & - \\
\hline słoweński & 317 & 4 & 313 & 54 \\
\hline chorwacki & 52 & - & 52 & - \\
\hline serbski & 80 & - & 80 & - \\
\hline
\end{tabular}

W oparciu o powyższe dane można wstępnie wyróżnić co najmniej dwie grupy: północno-wschodnią, charakteryzującą się wysoką frekwencją geminat (powyżej trzystu geminat w tekście) i południowo-zachodnią z niższą frekwencją. $\mathrm{W}$ pierwszej grupie ponadto istnieje więcej pozycji, $\mathrm{w}$ których geminaty są akceptowane - prócz granicy morfologicznej geminaty mogą występować także wewnątrz morfemów (głównie w wyrazach obcych, ale nie tylko) i na słabych szwach morfologicznych - wewnątrz tematów fleksyjnych. Poza śródgłosem w językach tej grupy geminaty występują także w nagłosie wyrazów prozodycznych. W językach północnosłowiańskich geminaty nagłosowe są relatywnie częste, na południu raczej unikane. Jedynymi językami, w których spotykamy nagłosowe geminaty wewnątrzmorfemowe, są polski ( $d \dot{z} d \dot{z} u, c z c z y)$ i ukraiński (лляmu). Warto podkreślić, że literatura przedmiotu wspomina też o możliwości realizacji geminat w wygłosie wyrazów (w szczególnych warunkach: wymowa bardzo staranna, akcent frazowy na danym wyrazie) - takie opinie wyrażano w odniesieniu do dwóch języków, w szczególnie starannej realizacji w polskim (np. w fontann, stall, 
por. Sawicka w Dukiewicz \& Sawicka, 1995) i w rosyjskim (np. w nymч, мamч, por. Grzybowski, 2007, s. 81).

W grupie z wyższą frekwencją geminat wyjątkowo wysoką częstotliwością wyróżnia się wschodnia słowiańszczyzna, w drugiej grupie - wyjątkowo niską wyróżniają się języki górnołużycki i dolnołużycki.

Granica między dwiema grupami języków słowiańskich, wyróżnionymi ze względu na badany problem, biegnie wzdłuż Karpat, a na południu kończy się w Bułgarii - bułgarski i słoweński ze względu na frekwencję geminat w tekście należą raczej do grupy północno-wschodniej, ale wyraźnie zaznacza się także ich przejściowy charakter, mają one geminat więcej niż w pozostałych językach południowosłowiańskich, mniej niż w północno-wschodnich. Przejściowy charakter ma także słowacki, który, poprzez wyższą frekwencję geminat niż w językach południowosłowiańskich i w języku czeskim, nawiązuje do wschodniej słowiańszczyzny.

Poprawność uzyskanych wyników potwierdza fakt, że wytyczona granica (i pasma przejściowe) pokrywa się z podziałem słowiańszczyzny ze względu na kilka innych istotnych typologicznie cech fonetycznych. Języki północno-wschodniej grupy mają zwłaszcza silniej rozwinięte inwentarze spółgłosek, głównie ze względu na rozbudowaną korelację palatalności, charakteryzują się palatalnością asymilacyjną i w ogóle częstszymi upodobnieniami spółgłosek, mają większą liczbę grup spółgłoskowych i często redukcje samogłosek nieakcentowanych, a także odstępstwa od jednoszczytowego modelu sylaby. Południowy zachód na ogół ma obszerny inwentarz samogłosek (między innymi dzięki dystynktywnej długości), niewielką ilość upodobnień, przeważnie też ograniczenia w sandhi dźwięcznościowym, i generalnie bardziej precyzyjną artykulację. Do tego dochodzą jeszcze pewne różnice syntofonologiczne i prozodyczne ${ }^{3}$. Tak bułgarska, jak i słoweńska fonetyka są nieco heterogeniczne pod względem cech istotnych typologicznie. Różnice między tymi blokami powoli się niwelują - głównie dzięki słabnięciu zjawisk asymilacyjnych i słabnącej miękkości spółgłoskowej (twardnieniom, rozłożeniom, ograniczeniom dystrybucyjnym i defonologizacjom miękkości na północy) i likwidowaniu niektórych dwuszczytowych sylab. Również różnica, obecność vs. brak geminat, jak widać, przybrała bardziej łagodną postać i przekształciła się w różnicę: duża liczba geminat w tekście vs. mała ich liczba.

Mimo iż uzyskane liczby dają wiarygodny obraz, to jednak wyniki te powinny potwierdzić dalsze badania na większych próbkach i na tekstach uzyskanych w inny sposób.

3 Uogólnienia tego rodzaju zawarte są w Sawicka (2001, 2007). 
Uzyskane wyniki potwierdzają to, że problem geminacji jest dla słowiańszczyzny istotny, i uzasadniają podjęcie dalszych badań w tym kierunku. Wyniki przedstawione w tej pracy należy traktować jako wstępny, konieczny, etap pracy nad zagadnieniem.

Kolejną potencjalną różnicę typologiczną może stanowić przeważający sposób realizacji geminat w poszczególnych językach. Wykonane dotychczas sondażowe spektrogramy nie pozwoliły na stwierdzenie typologicznie istotnej różnicy $\mathrm{w}$ artykulacji geminat szczelinowych - we wszystkich językach była to realizacja wzdłużona (lub z bardzo niewielkim spadkiem poziomu intensywności między dwoma segmentami geminaty). Natomiast wydaje się, że takie różnice występują w artykulacji okluzywnej geminaty na silnej granicy morfologicznej. Jest to podział na języki zachodniosłowiańskie z jednej strony, i pozostałe języki słowiańskie $\mathrm{z}$ drugiej. $\mathrm{W}$ tych pierwszych, na silnej granicy prefiksalnej/przyimkowej w realizacji geminaty dwóch zwartych wystąpiły dwie (a czasem nawet więcej) plozji, podczas gdy w pozostałych językach po przedłużonym zwarciu plozja była jedna.

Poniżej przytaczam przykłady różnie realizowanej geminaty okluzywnej (spektrogramy wykonane programem Praat 5361 [praat5361 win32.zip]).

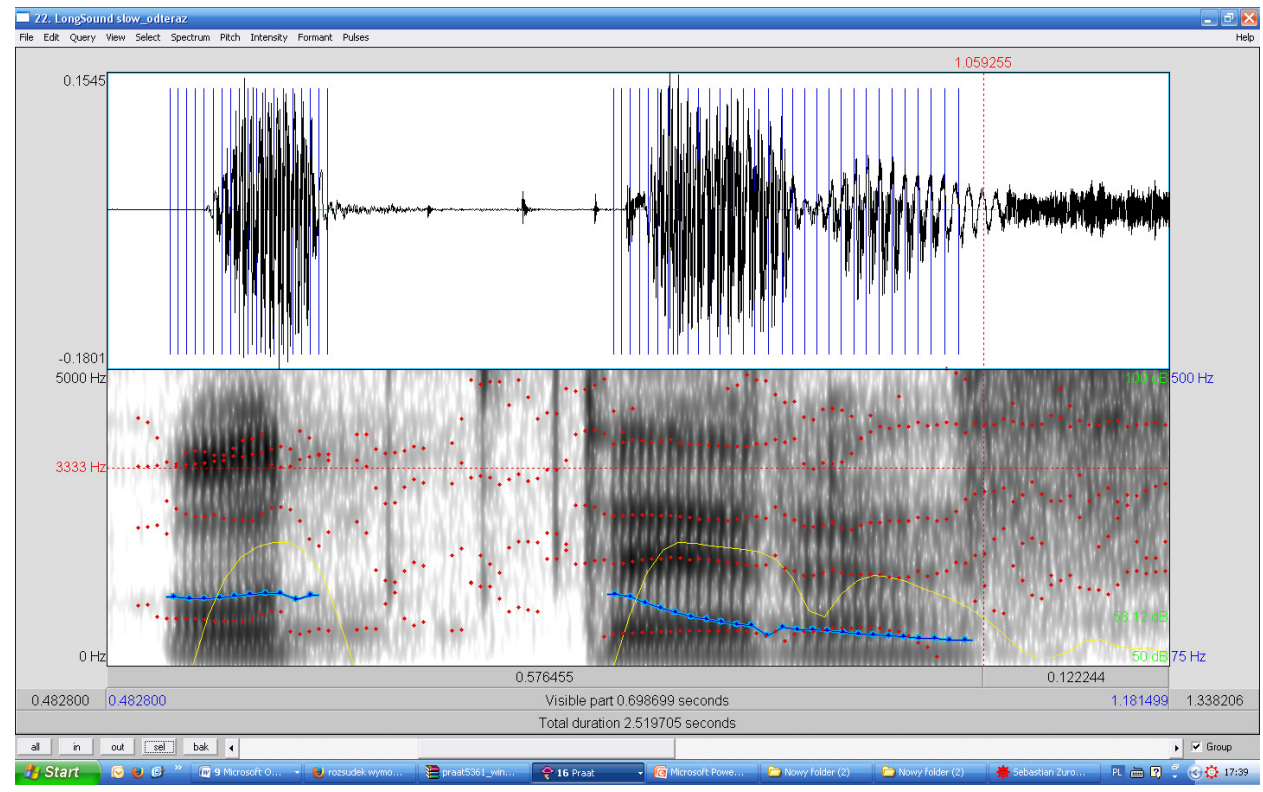

Ryc. 1. Oscylogram i spektrogram słowackiego odteraz [otteraz] 


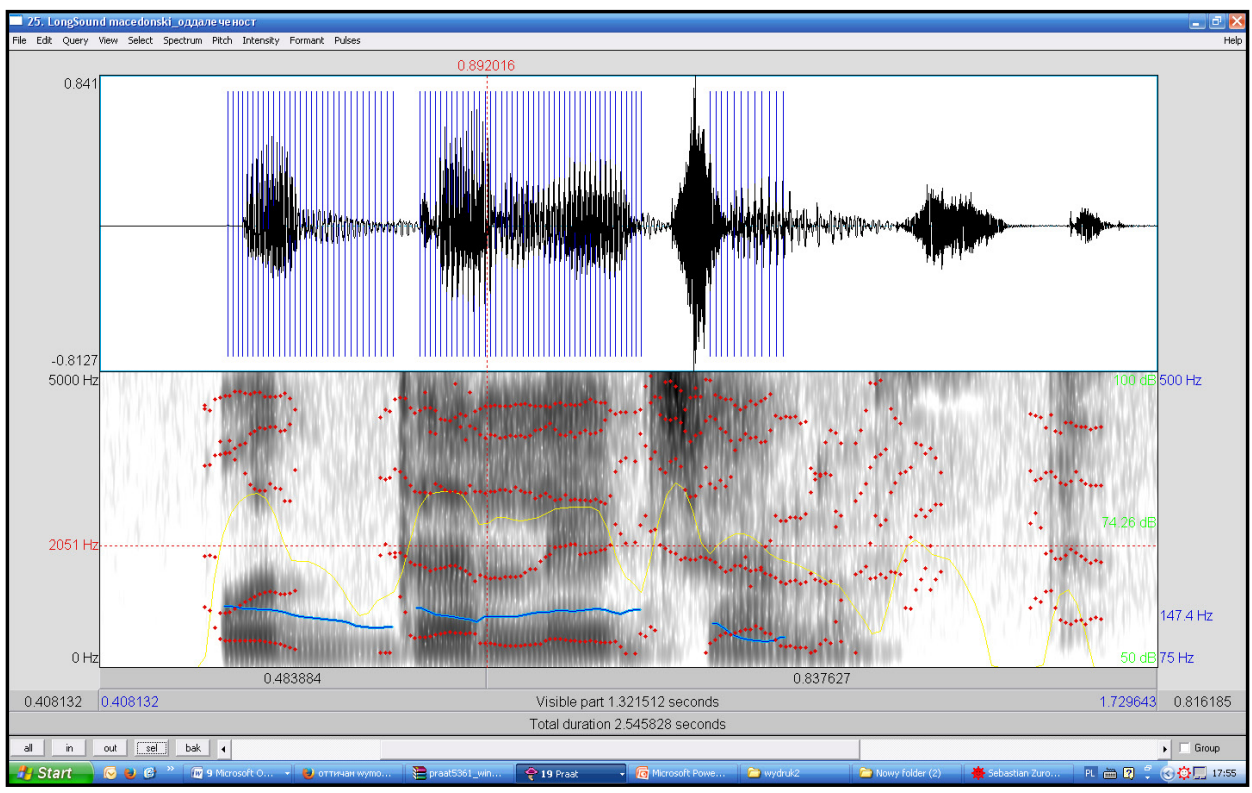

Ryc. 2. Oscylogram i spektrogram macedońskiego оддалеченост

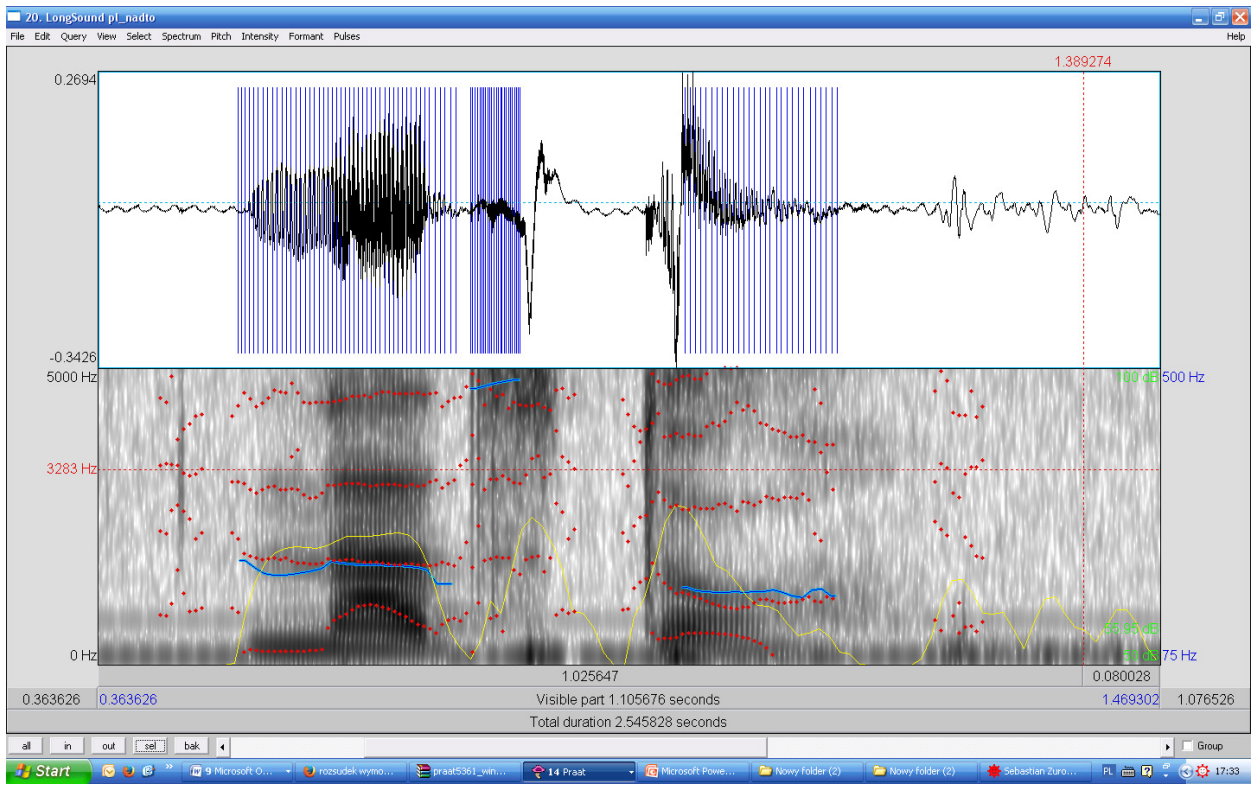

Ryc. 3. Oscylogram i spektrogram polskiego nadto 


\section{BIBLIOGRAFIA}

Bajerowa, I., \& Wieczorkowa, A. (1989). Uwagi o pisowni polskich druków XVII-wiecznych. Prace Naukowe Uniwersytetu Śląskiego, (17(1061)), 9-22.

Cychnerska, A. (2012). Sandhi w standardzie języka macedońskiego. Toruń: UMK.

Cychnerska, A. (Red.). (2013). Sandhi w językach słowiańskich. Toruń: UMK.

Dukiewicz, L., \& Sawicka, I. (1995). Gramatyka współczesnego języka polskiego: Fonetyka i fonologia. Kraków: Instytut Języka Polskiego PAN.

Grzybowski, S. (1986). Gramatyka opisowa współczesnego języka rosyjskiego (Cz. 1: Fonetyka. Fonologia). (A. Bartoszewicz \& J. Wawrzyńczyk, Red.). Warszawa: PWN.

Grzybowski, S. (2007). Zarys fonetyki opisowej języka rosyjskiego (wraz ź́wiczeniami) [Краткий очерк фонетики русского языка (с упражнениями)]. Toruń: UMK.

Jakobson, R. (1962). К характеристике евроазийского языкового союза. W R. Jakobson, Selected writings. S'-Gravenhage: Mouton.

Korytowska, A. (2001). Grupy samogłoskowe w językach słowiańskich (Nieopublikowana rozprawa doktorska). Uniwersytet Mikołaja Kopernika, Toruń.

Kozyra, A. (2014). Geminacja spółgłoskowa w językach słowiańskich (Nieopublikowana rozprawa doktorska). Uniwersytet Mikołaja Kopernika, Toruń.

Pianka, W., \& Tokarz, E. (2000). Gramatyka konfrontatywna języków słowiańskich (T. 1). Katowice: „Śląsk”.

Sawicka, I. (1974). Struktura grup spółgłoskowych w językach słowiańskich. Wrocław: Ossolineum.

Sawicka, I. (1986). Struktura sloga u balkanskim jezicima. Wrocław: Ossolineum.

Sawicka, I. (2001). An outline of the phonetic typology of the Slavic languages. Torun: UMK.

Sawicka, I. (Red.). (2007). Komparacja współczesnych języków słowiańskich (T. 2: Fonetyka i fonologia). Opole: Uniwersytet Opolski - Instytut Filologii Polskiej.

Serowik, A. (1998). Sposób realizacji geminat w polszczyźnie. Studia Slavica, 3, 159-177.

Zinowiewa, T. (1998). Zagadnienia sandhi w języku rosyjskim w porównaniu z polskim (Nieopublikowana rozprawa doktorska). Uniwersytet Mikołaja Kopernika, Toruń.

Лекомцева, М. (1968). Типология структур слога в славянских языках. Москва: „Наука”.

Толстая, С. М. (1968а). Сочетаемость согласных в связи с фонологической структурой слова в славянских языках. Советское славяноведение, (1), 41-45.

Толстая, С. М. (1968b). Фонологическое расстояние и сочетаемость согласных в славянских языках. Вопросы языкознания, (3), 66-68.

Толстая, С. М. (1974). К характеристике консонантных сочетаний в славянских языках. Slavia, 42, 113-134. 


\section{BIBLIOGRAPHY}

\section{(TRANSLITERATION)}

Bajerowa, I., \& Wieczorkowa, A. (1989). Uwagi o pisowni polskich druków XVII-wiecznych. Prace Naukowe Uniwersytetu Śląskiego, (17(1061)), 9-22.

Cychnerska, A. (2012). Sandhi w standardzie języka macedońskiego. Toruń: UMK.

Cychnerska, A. (Ed.). (2013). Sandhi w językach słowiańskich. Toruń: UMK.

Dukiewicz, L., \& Sawicka, I. (1995). Gramatyka współczesnego języka polskiego: Fonetyka i fonologia. Kraków: Instytut Języka Polskiego PAN.

Grzybowski, S. (1986). Gramatyka opisowa współczesnego języka rosyjskiego (Part 1: Fonetyka. Fonologia). (A. Bartoszewicz \& J. Wawrzyńczyk, Eds.). Warszawa: PWN.

Grzybowski, S. (2007). Zarys fonetyki opisowej języka rosyjskiego (wraz ź́wiczeniami) [Kratkiŭ ocherk fonetiki russkogo iazyka (s uprazhneniiami)]. Toruń: UMK.

Jakobson, R. (1962). K kharakteristike evroaziǔskogo iazykovogo soiuza. In R. Jakobson, Selected writings. S'-Gravenhage: Mouton.

Korytowska, A. (2001). Grupy samogłoskowe w językach słowiańskich (Unpublished doctoral dissertation). Uniwersytet Mikołaja Kopernika, Toruń.

Kozyra, A. (2014). Geminacja spółgłoskowa w językach słowiańskich (Unpublished doctoral dissertation). Uniwersytet Mikołaja Kopernika, Toruń.

Lekomtseva, M. (1968). Tipologiia struktur sloga v slavianskikh iazykakh. Moskva: „Nauka”.

Pianka, W., \& Tokarz, E. (2000). Gramatyka konfrontatywna języków słowiańskich (Vol. 1). Katowice: „Śląsk”.

Sawicka, I. (1974). Struktura grup spółgłoskowych w językach słowiańskich. Wrocław: Ossolineum.

Sawicka, I. (1986). Struktura sloga u balkanskim jezicima. Wrocław: Ossolineum.

Sawicka, I. (2001). An outline of the phonetic typology of the Slavic languages. Toruń: UMK.

Sawicka, I. (Ed.). (2007). Komparacja współczesnych języków słowiańskich (Vol. 2: Fonetyka i fonologia). Opole: Uniwersytet Opolski - Instytut Filologii Polskiej.

Serowik, A. (1998). Sposób realizacji geminat w polszczyźnie. Studia Slavica, 3, 159-177.

Tolstaia, S. M. (1968a). Sochetaemost' soglasnykh v sviazi s fonologicheskoŭ strukturoŭ slova v slavianskikh iazykakh. Sovetskoe slavianovedenie, (1), 41-45.

Tolstaia, S. M. (1968b). Fonologicheskoe rasstoianie i sochetaemost' soglasnykh v slavianskikh iazykakh. Voprosy iazykoznaniia, (3), 66-68.

Tolstaia, S. M. (1974). K kharakteristike konsonantnykh sochetaniı̌ v slavianskikh iazykakh. Slavia, 42, 113-134.

Zinowiewa, T. (1998). Zagadnienia sandhi w języku rosyjskim w porównaniu z polskim (Unpublished doctoral dissertation). Uniwersytet Mikołaja Kopernika, Toruń. 


\section{Geminaty w językach słowiańskich}

Tematem artykułu jest występowanie geminat w językach słowiańskich. Badanie frekwencji geminat na podstawie pięćdziesięciostronicowych tekstów, czytanych przez rodzimych użytkowników języka, nie potwierdziło popularnej opinii, że występowanie vs. brak geminat stanowi cechę typologiczną, różnicującą języki słowiańskie. Badanie wykazało natomiast, że dziś typologicznie istotne są różnice we frekwencji występowania geminacji.

Słowa kluczowe: języki słowiańskie; fonetyka; geminaty

\section{Geminates in the Slavic Languages}

The subject of the article is the occurrence of geminates in Slavic languages. Research on the frequency of geminated consonants is based on 50-page texts read by native speakers. The results did not confirm the popular opinion that the occurrence vs. lack of geminates is a typological feature differentiating Slavic languages. The study showed, however, that today typologically significant difference between Slavic languages is the one in frequency of the occurrence of geminates.

Keywords: Slavic languages; phonetics; geminates

\section{Notka o autorce}

Anna Kozyra (lenaandkukula@poczta,onet.pl) - slawistka. Zainteresowania badawcze: fonetyka i typologia fonetyczna języków słowiańskich.

Anna Kozyra (lenaandkukula@poczta,onet.pl) - Slavicist. Her interests include phonetics and phonetic typology of the Slavic languages. 